\title{
Ion channels alteration in dilated cardiomyopathy in human heart
} Viktoria Szüts*1, István Baczkó1, Dalma Ménesi ${ }^{4}$, Zoltán Varga-Orvos ${ }^{4}$, János Zs Kelemen ${ }^{4}$, László G Puskás ${ }^{4}$, Zoltán Bódi ${ }^{1}$, Lajos Csincsik ${ }^{1}$, Nazamin Houshmand ${ }^{1}$, Miklós Bitay², Miklós Csanády ${ }^{2}$, Norbert Jost ${ }^{1,3}$, László Virág ${ }^{1}$, Julius Gy Papp ${ }^{1,3}$ and András Varró ${ }^{1}$

Address: ${ }^{1}$ Department of Pharmacology and Pharmacotherapy, University of Szeged, Hungary, 2 2nd Department of Internal Medicine, Cardiology Center, Cardiac Surgery, University of Szeged, Hungary, ${ }^{3}$ Division of Cardiovascular Pharmacology, Hungarian Academy of Sciences, Szeged, Hungary and ${ }^{4}$ Laboratory of Functional Genomics, BRC, Hungarian Academy of Sciences, Szeged, Hungary

Email: Viktoria Szüts* - szuts@phcol.szote.u-szeged.hu

* Corresponding author

from 13th Scientific Symposium of the Austrian Pharmacological Society (APHAR). Joint Meeting with the Austrian Society of Toxicology (ASTOX) and the Hungarian Society for Experimental and Clinical Pharmacology (MFT)

Vienna, Austria. 22-24 November 2007

Published: 14 November 2007

BMC Pharmacology 2007, 7(Suppl 2):A5I doi:10.1 186/I47I-2210-7-S2-A5I

This abstract is available from: http://www.biomedcentral.com//47I-22/0/7/S2/A5 I

(C) 2007 Szüts et al; licensee BioMed Central Ltd.

The complex mechanism by which genes are mostly involved in cardiomyopathy (clinical heart failure) is not resolved. Cardiac ion channels are shown as a mixture of homomeric and heteromeric tetramers composed of closely related subunits from homo- or heteromeric assembly of $\alpha$ and $\beta$ subunits, and underlie the main part of the currents. The aim of this study was to compare the expression of the ion channels and regulatory genes in ventricular muscle between failing and non-failing human heart. We also tested the marker genes of inflammation, fibroblast, neuronal tissues and vascular vessels. Therefore, we have quantified the pore-forming $\alpha$ and auxiliary $\beta$ subunit-coding mRNAs of $\mathrm{I}_{\mathrm{Ca}^{\prime}} \mathrm{I}_{\mathrm{Na}^{\prime}}, \mathrm{I}_{\mathrm{to}^{\prime}} \mathrm{I}_{\mathrm{Kr}^{\prime}} \mathrm{I}_{\mathrm{Ks}^{\prime}}$ $\mathrm{I}_{\mathrm{K} 1}$ channels and regulatory genes by real-time qPCR (BioTrove) in left ventricle of heart tissues. Coding genes for sodium ion channels have marked differences in failing and control tissues of left ventricular muscle. Our results suggest that coding genes for $\mathrm{Na}^{+} / \mathrm{Ca}^{2+}$ exchange current is mostly upregulated in dilated cardiomyopathies patients heart while $\mathrm{Na}_{\mathrm{V}} 1.5$ is much less. Potassium ion channel $\alpha$ and $\beta$ subunits exhibit different distribution in the failing ventricle tissues versus control. These findings may provide insight into a mechanism responsible for hearth failure, DCM, HCM and RCM due to several regulatory genes- related up- or down-regulation of sodium, calcium, chloride and potassium ion channels.

\section{Acknowledgements}

This work was supported by grants from OTKA 5K-522 and 5W022. 